UDK: 343.261(497.4)

doi:10.5937/crimen1903225F

ORIGINALNI NAUČNI RAD

Prihvaćeno: 31.102019.

\author{
Katja Filipčič $\check{c}^{\star}$ \\ Faculty of Law, University of Ljubljana, Slovenia
}

\title{
LIFE IMPRISONMENT IN SLOVENIA
}

\begin{abstract}
In 2008, Slovenia introduced the punishment of life imprisonment. Since then it can be imposed for certain crimes against humanity and for the (at least two) crimes of intentional homicide. The proposal for introducing life imprisonment was founded on two arguments: the introduction of life imprisonment being necessary to harmonise Slovenian law with the Rome Statute of the International Criminal Court and to harmonise it with the majority of European countries. In public debate, both arguments were rejected as false, while opponents of life imprisonment cited reasons against introducing it (e.g., rehabilitation as a purpose of punishment, respect for human dignity, the inefficiency of severe sentences). In the public debate, also elements of penal populism could be noticed. Although most experts opposed the introduction of life imprisonment, it was adopted in the Slovenian Criminal Code. In 2016, the Ministry of Justice at first proposed abolishing it, but the final political decision was different. A proposal to abolish the life imprisonment was withdrawn from the 2016 amendment to the Criminal Code and the Parliament did not vote on the proposal at all. Although the punishment of life imprisonment has been now a part of Slovenian law for eleven years, it has not yet been imposed.
\end{abstract}

Keywords: life imprisonment, the Rome Statute, penal policy, punitive populism, human rights

\section{INTRODUCTION}

In most European countries, the punishment of life imprisonment was introduced after the abolition of the death penalty, i.e. as a substitute for it, and, therefore, at the time of its introduction represented a reduction in repression. The underlying reason for the abolition of the death penalty was respect for human rights, ${ }^{1}$ also reflected in the adoption of Protocol 6 to the European Convention on Human Rights on the Abolition of the Death Penalty in 1983. In Slovenia, however, the story of the introduction of life imprisonment is different. Slovenia abolished the death penalty in 1989 (the last execution was carried out in 1957) and was then content

Associate Professor, katja.filipcic@pf.uni-lj.si .

1 More in: D. Van Zyl Smit and C. Appleton /2019/: Life Imprisonment: a global human rights analysis, Harvard University Press, Cambridge, Massachusettes. 
with the highest prison sentence of 20 years imprisonment. However, it introduced life imprisonment 19 years after the abolition of the death penalty (in 2008) as an alternative to 30 years in prison for some of the most heinous crimes. Nor an actual atrocious crime had been committed that could have received abundance of media attention and could have given direct rise to incorporation of life imprisonment into Slovenian criminal law due to public outcry. Thus, at first glance, it appears that the introduction of life imprisonment into Slovenian criminal law was the result of deliberate professional discussion and consensus within the profession. However, this was not the case. The article will outline the process of its adoption and the arguments for and against the introduction of the life imprisonment that were raised during the public debate. First, however, the characteristics of life imprisonment in Slovenian penal legislation will be presented.

\section{LIFE IMPRISONMENT IN SLOVENIAN CRIMINAL LAW}

Life imprisonment was introduced into Slovenian criminal law with the adoption of the new Criminal Code in 2008. ${ }^{2}$ It can be imposed for two sets of offences for which a prison sentence of between 15 and 30 years is otherwise prescribed.

The first group of crimes is composed of four criminal offences against humanity (genocide, crimes against humanity, war crimes and aggression). These offences also fall within the subject-matter jurisdiction of the International Criminal Court under Article 5 of the Rome Statute. In fact, the definitions of these crimes in the Slovenian Criminal Code are directly mapped to the Rome Statute descriptions.

The second group of crimes includes forms of intentional deprivation of life: aggravated form of terrorism, assassination of the President of the Republic, aggravated threat of persons under international protection, aggravated taking of hostages, aggravated forms of certain crimes against the sovereignty of the Republic of Slovenia and its democratic constitutional organization and criminal offence of homicide. ${ }^{3}$ Unlike the offences in the first group, life imprisonment may be imposed only if the offender has committed two or more such offences for which he

2 Criminal Code (Kazenski zakonik - KZ-1), Official Gazette of the Republic of Slovenia, No. $55 / 08$.

3 In the Slovenian Criminal Code, homicide is defined in Article 116:

"Whoever murders another human being by taking his life

1) in a cruel or perfidious manner;

2) due to taking action in official acts to protect public security, or in a pre-trial criminal procedure, or due to decisions of state prosecutors, or due to the proceeding and decisions of judges, or due to criminal complaint, or testimony in a court proceeding;

3) because of violation of equality;

4) out of desire to murder, out of greed, in order to commit or to conceal another criminal offence, out of unscrupulous vengeance, or from other base motives;

5) with the act committed within a criminal organisation to commit such offences, shall be sentenced to imprisonment for not less than fifteen years." 
or she is being tried at the same time and if the court has imposed a sentence of 30 years imprisonment for two or more offences merger. Under these conditions, therefore, life imprisonment shall be imposed as a single sentence.

The offender sentenced to life imprisonment may be released on parole after he or she has served twenty-five years in prison.

If a life sentence was imposed, the pardon or amnesty shall impose a sentence of imprisonment between twenty-five and thirty years. In such case, it should be considered that the punishment of imprisonment of such length was imposed and, therefore, release on parole is possible according to the rules applicable to such sentence (i.e. after three-quarters of the sentence served).

\section{THE PROCEDURE OF ADOPTION OF LIFE IMPRISONMENT INTO SLOVENIAN LEGISLATION}

\subsection{Critique of the Proposed Criminal Code}

A group consisting of only three members (a Supreme Court judge and two criminal law professors), on the contract of the Ministry of Justice (hereinafter referred to as the Ministry), prepared a proposal for a new Criminal Code. The Ministry presented the proposal to the public at the end of 2007. The professional public was astonished, as it was not known that the preparation of the text of the new law was underway. Besides, a short, only three-month public debate was scheduled. The bill contained several significant changes to both the general and special part of the Criminal Code, which proved to be ill-conceived and controversial. Besides individual solutions, criticism of the professional public was primarily aimed at rushing to adopt the Criminal Code as one of the most essential laws of any state with the rule of law. Here, the ambivalent nature of criminal law must be taken into account. On the one hand, criminal law enables the state the most significant human rights interferences, and on the other, it sets boundaries for such interferences. ${ }^{4}$ Therefore, the manner of the Code's adoption must be transparent, accompanied by an in-depth debate, and the state must provide sufficient time to come up with sound solutions.

The Ministry only allowed a three-month public debate. The exchange of arguments for and against the proposed novelties was lively and controversial, taking place in public panel discussions, on television shows, as well as in professional and general press. In the public debate, most attention was paid to the proposed introduction of life imprisonment. However, the criticism aimed at some other proposed changes to the general part of the Criminal Code, as well, such as: ${ }^{5}$

4 A. Šelih /2007a/: Ali potrebujemo nov kazenski zakonik?, Delo.

5 A. Šelih /2007a/: op. cit.; K. /2008/: Premalo pretehtani posegi v temeljne institute kazenskega prava: o predlogu kazenskega zakonika. Delo, 26. 1. 2008, n 21; K. Filipčič /2007/: Časovna odmerjenost učinkov kaznovanja v KZ-1. Pravna praksa, n 46, pp. XIV-XVI; M. Ambrož /2008/: Spremembe slovenske materialne kazenske zakonodaje in argument primerjalnega prava, Podjetje in delo, n. 6/7, pp. 1420-1426; M. Ambrož /2007/: Nova zgradba kaznivega dejanja v predlo- 
- New regulation of the institute of necessity;

- The abolition of the institute of the offence of minor importance;

- Unusual definition of consent of the injured party;

- Change in the definition of negligence;

- Change of the statute of limitations;

- Exclusion of medical security measures from criminal law.

The authors of the draft law rarely participated in the discussions, and due to the summary clarifications of the proposal, we could only guess why the individual proposals were made at all. At the time of the public debate, the Faculty of Law of the University of Ljubljana organised a conference on the proposed new Criminal Code attended by 250 individuals and not even a single participant supported the bill (neither the proposed life imprisonment). Television confrontations and especially discussions published in professional journals and public media, were polemic. Defenders and opponents of life imprisonment were alleging the polemic ceased to be ad rem but instead turned into ad personam attacks. ${ }^{6}$ The public debate lasted for three months and was concluded with the approval of the bill by the government and the commencement of the legislative process in January 2008. Some comments from the public debate were taken into consideration by the Ministry, but most were not, and the Criminal Code was adopted (together with the introduction of life imprisonment) and entered into force on 1 November 2008.

\subsection{Life Imprisonment - Pro et Contra}

Compared to other proposed changes to the criminal law, the debate about life imprisonment was most heated. It included experts in the fields of criminal law, theory of law, philosophy, criminology and international law. The proposed introduction of life imprisonment received very little support, and many voiced their opposition to it. In the debate, the proponents themselves were most restrained. They penned their arguments into the bill itself, only one of them contributed an article in a professional journal, ${ }^{7}$ and their appearances in television interviews and confrontations were only slightly more frequent.

The arguments of the proposers of life imprisonment can be divided into two groups: arguments for the introduction of life imprisonment for offences defined as the most serious crimes by Slovenian criminal law implementing the Rome Statute and arguments for the imposition of life imprisonment for merged crimes when the offender commits two or more crimes of intentional homicide.

gu KZ-1, Pravna praksa, n 41/42, pp. II-IV; M. Ambrož /2008b/: Poveljniška odgovornost in predlog KZ-1, Pravna praksa, n 15, pp. 21-22; D. Korošec /2007/: Temeljno o splošnem pojmu kaznivega dejanja, Pravna praksa, $\mathrm{n}^{\circ} 46$, pp. VI-X.

6 M. Deisinger /2008/: Nekatere kazenske sankcije v osnutku KZ-1. Pravna praksa, n 2, pp. 14-16; A. Šelih /2007/: Kazensko pravo kot zakonsko parvo, Pravna praksa, n 46, pp. II-V.

7 M. Deisinger /2008/: op. cit. 


\subsubsection{Introduction of Life Imprisonment as Harmonisation with the Rome Statute}

Much attention was paid to the argument of the proposers in the debate that the introduction of life imprisonment was necessary to comply with the Rome Statute, which Slovenia ratified on 22 November 2001. It, therefore, referred exclusively to the punishment of four offences under the Rome Statute (Article 5), for which the Statute provides for life imprisonment if justified by the exceptional gravity of the crime and the personal circumstances of the offender (Article 77).

According to the proposers, without such harmonisation, Slovenia would not have been able to conduct the trial for the offences set out in the Rome Statute or execute the sentence of life imprisonment imposed by an international court. If Slovenia did not impose life imprisonment, even though it is a party to the treaty establishing an international court, according to the proposers, it would be justifiably labelled a non-credible state. ${ }^{8}$

A controversial debate arose as to whether Slovenia was obliged, as a signatory to the Rome Statute, to prescribe life imprisonment for crimes defined in national law. The proponents even stated (entirely wrongly) that if Slovenia tried the alleged perpetrators of these crimes under national law, it could pronounce such sentence, even though it would not be enacted in Slovenian law. ${ }^{9}$ Several authors rejected such arguments. ${ }^{10}$ They clarified that the Rome Statute did not impose "an obligation to States to implement the substantive provisions of the Statute into their respective criminal laws". 11 They also stressed that, with respect to penalties, Article 80 of the Rome Statute explicitly stated that no provision of the Statute on penalties affects the application by States of penalties prescribed by their national law. ${ }^{12}$ Should the International Criminal Court pronounce a sentence of life imprisonment, such punishment shall be served "in a State designated by the Court from a list of States which have indicated to the Court their willingness to accept sentenced persons" (Article 103 of the Rome Statute). "It is, therefore, a possibility, not an international obligation of the States". ${ }^{13}$ Even if the State expresses its willingness to accept the sentenced person, it may impose conditions (Articles 103 and 105 of the Statute), which may include the indication that national law does not provide for the sentence to be enforced, and it is, therefore, not enforceable by the Member State. The Rome Statute as regards the imprisonment imposed by the International Criminal Court enforces a consensual model ${ }^{14}$ and in no way imposes an unconditional obligation upon States to enforce the sentence imposed.

8 Criminal Code Proposal, EVA 2007-2011, 11 October 2007.

9 M. Deisinger /2008/: op. cit.; M. Deisinger /2008a/: Kdo se še spomni na holokavst?, Pravna praksa, $\mathrm{n}^{\circ} 4$, p. 21.

10 See, for example: L. Bavcon /2007/: Ali bi Slovenija zmogla brez kazni dosmrtnega zapora?, Pravna praksa, $\mathrm{n}^{\circ} 39 / 40$, pp. 23-25; A. Novak /2007/: Dosmrtni zapor na trhlih temeljih, Pravna praksa, $\mathrm{n}^{\circ} 41 / 42$, pp. VI-VIII.

11 L. Bavcon: op. cit.

12 L. Bavcon: ibid.

13 A. Novak /2007/: op. cit.

14 M. Ambrož /2008a/: Izvršitev zaporne kazni, ki jo izreče MKS, Pravna praksa, n 13, pp. 21-22. 
The opinion of the Office of Legislation of the Government of the Republic of Slovenia was also unambiguous (No. 710-5/2007-Š of 2 November 2007). After a careful analysis of the provisions of the Rome Statute, the Government Office concluded that "the Rome Statute does not in any way require the introduction of this penalty in our legislation, and that it is, therefore, professionally wrong to assert or argue that this is in line with the Rome Statute."

Beside the (false) allegations of Slovenia's legal obligation to comply with the Rome Statute, the proposers argued that by introducing a life imprisonment, Slovenia would have demonstrated that it was a credible signatory to the international treaty and that, in value terms, evaluates the most aggravated forms of the worst crimes against humanity in the same way as most of the international community by prescribing the sentence of life imprisonment for such acts. ${ }^{15}$ This argument was counteracted in the debate that Spain and Portugal, which do not have life imprisonment, cannot be labelled as untrustworthy since such a claim would be not only inappropriate but also offensive. Novak stressed that it was more credible for a country to maintain its ethical conviction of appropriate punishment than to submit to its imaginary obligations so as not to deviate too much from some other countries. ${ }^{16}$

A predominant view in the public debate was that the arguments about the legal obligation to introduce life imprisonment for the sake of harmonisation with the Rome Statute were false and absurd. ${ }^{17}$ Therefore, the decision to introduce such a sanction was labelled as highly political, with its proponents endeavouring to justify it by legal arguments. ${ }^{18}$

\subsubsection{Introduction of Life Imprisonment for the Sake of Harmonisation with the European Law}

The proposed new Criminal Code also provided for life imprisonment for two or more offences of deliberate homicide for which a prison sentence of up to thirty years was prescribed (the proposers listed these offences), with the additional condition that the court imposes a sentence of imprisonment of thirty years for two merged offences each individually.

The proposer justified the introduction of life imprisonment for this group of crimes only on the basis that most EU countries had such a sentence and that, by introducing life imprisonment, Slovenian legislation would be in line with the laws of most EU countries. In a subsequent public debate, the proposers supplemented their argument by stating that by introducing a life imprisonment, Slovenia would approach the 24 European countries (which had the sentence at the time) in a mitigated form, since, with respect to homicide, the possibility of imposing was proposed only for merger of the most severe forms of homicide, subject to the

15 M. Deisinger /2008/: op. cit.

16 A. Novak /2008/: Nepotrebnost usklajevanja kazenskih sankcij z Rimskim statutom, Pravna praksa, $\mathrm{n}^{\circ} 3$, pp. 17-18.

17 D. Petrovec /2007/: Meje lojalnosti, Pravna praksa, nº 41/42, pp. IX.

18 A. Novak /2008/: op. cit. 
additional condition of two or more imposed sentences of thirty years imprisonment. ${ }^{19}$ Thus, life imprisonment could be imposed only for the most extreme (and rare) cases.

Opponents of life imprisonment argued that European criminal law did not require the harmonisation of legal systems, nor did it require harmonisation of criminal sanctions. In the discussion, it was also pointed out that a comparative legal argument could be a "convincing supporting argument, but at the same independent substantive reasons must exist supporting a particular legislative solution. But obviously there were none of them". ${ }^{20}$ Namely, the proposer did not conduct any analysis on the crime trends or on the number of crimes for which it proposed life imprisonment and, therefore, had not based the proposal on the need for possible increased crime rates. If indeed it had performed such an analysis, it would not have been able to base its proposal for the introduction of life imprisonment, as the number of the most serious crimes declined during that period. Besides, many studies demonstrate that the level of criminality does not depend on the severity of the penalties prescribed and imposed but rather on numerous other factors.

\subsubsection{Life Imprisonment and the Value of Human Life}

The Criminal Code proposal cited only the two arguments analysed above, which were sharply criticised and rejected in the subsequent public debate. During a public discussion, however, the proposers criticised the opponents of life imprisonment that their opposition was indicative of "insensitivity to the deceased victims of the worst crimes"21 and that they had forgotten the issue of value of human life. A member of the group that drafted the new Criminal Code even referred to the "mathematical justice" of punishment (the Talion principle) when he calculated that if someone had committed genocide against the Chinese, he would have been imprisoned in Slovenia only for 1.37 seconds for each killed human being. ${ }^{22}$

Such views suggest an emphasis on victim-centred justice. It is undisputed that a concrete crime affects a concrete victim and that the state has an obligation to prosecute the perpetrator. However, in modern society, the victim's need to punish the perpetrator has been taken up by the state. The authority to punish was transferred from the victim to the state to free the punishment of the perpetrator from the victim's hands. The victim would decide on the form and severity of punishment based on his or her subjective notions of justice, his or her personality traits and the subjective experience of victimisation, while the perpetrator is entitled to an impartial trial. Therefore, punishment is impartially decided by the state (courts), which also pursues the same goals by punishing all perpetrators. In punishment, the state must also meet the expectations of the victims on the appropriate punish-

\footnotetext{
19 M. Deisinger /2008/: op. cit.

20 A. Novak /2007/: op. cit.

21 M. Deisinger /2008/: op. cit.

22 Cited in: B. Flander and M. Zupan /2007/: Domišlija rablja in ječarja, Pravna praksa, n 41/42, pp. II-VI.
} 
ment. However, taking into account, merely or primarily, the (different) expectations of victims as regards punishment would regress criminal law to its dark ages (public lynching, torture of convicts, summary trials without a fair procedure). This raises the question why time-limited prison sentences are not appropriate from the perspective of victims, as well. This question remained unanswered in the public debate.

However, if the role of victims is negligent or almost non-existent in criminal law, it is widely accepted in criminal law that the state is obliged to assist them in solving the problems resulting from being victimised by a crime; both through measures in criminal proceedings to reduce secondary victimisation, and through the establishment of programmes for the psychological support of victims and the creation of funds to recover the damage they have suffered as a result of the crime.

Emphasising the role of the victim and his or her dignity also opened discussions on the dignity of the convicted person. By punishing him or her, the state interferes with his or her rights and in the process sets its own limits. What should such restrictions be and what purpose should punishment pursue? In the discussions on the purpose of punishment, the ideas of retributivism and utilitarianism were discussed, ${ }^{23}$ as well as different starting points for thinking about justice. Thus, for instance, a supporter of the proposal to introduce life imprisonment wrote that the offender voluntarily committed the most infamous act, and his or her exclusion from everyday life restores to society a sense of justice, a fragment of moral compensation. ${ }^{24}$ There were numerous discussions on justice which demonstrated, in particular, the already known different conceptions of justice and the purpose of punishment, which also include value aspects and are derived from the answers to questions: What is human, to what extent does human responsibility extend, is society (co)responsible for individual's behaviour, what is the purpose of punishment?

Besides, opponents of life imprisonment also emphasised the importance of respecting the dignity and humane treatment of all those deprived of their liberty for committing a crime, as is already apparent from the International Covenant on Civil and Political Rights (Article 10). Bavcon thus argued that the sentence of life imprisonment was contrary to the International Covenant because it directly denied human dignity: "For life is not mere vegetation, bare survival, but it also encompasses the possibility and right to personal development, to creativity, freedom, emotional and social connection, etc." 25 Another interesting reasoning by Kmet should be noted, who responded to the proposers' belief that a person sentenced to life imprisonment could be conditionally released after 25 years and that the offender himself or herself would be able to achieve a time-limited sentence by his or her behaviour. Concerning parole, the author concludes, "the nature of a society cannot be judged by the privileges (parole) it grants, but by the cruelty it is capable of" ${ }^{26}$

23 B. Debenjak /2008/: Regeneracija besed pravica, pravičnost, krivda, umno ravnanje: o reformi kazenskega zakonika, Delo, 16. 2. 2008, $\mathrm{n}^{\circ} 38$.

24 B. Debenjak: ibid.

25 L. Bavcon: op. cit.

26 S. Kmet /2007/: Dosmrtni zapor - družba prezira?, Pravna praksa, n 41/42, pp. X-XI. 


\subsection{Penal Populism and Public Opinion}

Penal populism can be defined in many ways, most often denoting the actions of political actors when (actual or perceived) criminal orientation of the public is exploited or misused for their political gain. ${ }^{27}$ It is characterised by an expressive, emotional and irrational approach to the formulation of punitive policies, and as a rule is reflected in the reform of criminal law in the direction of escalation of punishment. ${ }^{28}$ It cannot be argued that the public debate on life imprisonment was riddled with penal populism as defined above because experts were usually involved in it. Politicians rarely expressed their views on life imprisonment. However, in some of the publicly uttered opinions of experts, we find elements of penal populism, especially in appearances by proponents of life imprisonment. ${ }^{29}$ Both of the primary arguments of the advocates (the need to impose life imprisonment to respect the international treaty and to harmonise punitive policy with other European countries), which the Ministry wrote in its explanation of the bill, have characteristics of penal populism. They proved to be legally unfounded, and the opponents of life imprisonment arguably dismissed them as false. However, both were also emotionally charged, as they were supported by the view that Slovenia would lose its reputation in the international community if it did not introduce a life sentence.

Elements of penal populism could also be noticed in some individual statements by proponents of life imprisonment, such as the mathematical calculation of the value of human lives in the case of a 30-year prison sentence for genocide against the Chinese or e.g. a question asked by one of the authors of the proposal to justify the life imprisonment from the perspective of victims: "Have we perhaps forgotten about the victims of the worst crimes that occurred in Srebrenica, Vukovar and Knin and the brutal serial killings in Slovenia?"30

Opponents of life imprisonment were far more convincing and less penal-populist in their arguments. ${ }^{31}$ The public debate moved from the professional journals to the public media, publishing not only journalistic articles but also summaries of statements made by various experts expressed in public appearances, interviews with experts and publishing their pieces in special sections, most often in "letters to the editor". An analysis of four newspapers (published daily) throughout the public debate revealed that the headlines for the articles were mostly neutral rather than sensationally or emotionally coloured; contributions that could be characterised as media "penal populism" were rare. ${ }^{32}$

27 B. Flander and G. Meško /2013/: Punitivnost in kaznovalni populizem v Sloveniji, Revija za kriminalistiko in kriminologijo, $\mathrm{n}^{\circ} 4$, pp. 330-344.

28 More on penal populism, e.g. Đ. Ignjatović /2017/: Kazneni populizam - in: Kaznena reakcija v Srbiji, VII deo, (Đ.Ignjatović, ed.), Beograd, Univerzitet u Beogradu - Pravni fakultet, Edicija Crimen, pp. 11-31.

29 B. Flander /2014/: Kaznovanje v Sloveniji (quo vadis) - in: Zbornik prispevkov, (B. Flander, I. Areh, M. Modic, eds.), Fakulteta za varnostne vede, Ljubljana, http://www.fvv.uni-mb.si/dv2014/ zbornik/Flander.pdf.

30 M. Deisinger /2008/: op. cit.

31 B. Flander /2014/: op. cit.

32 B. Flander and G. Meško /2013/: op. cit. 
Penal populism and public demands for a stricter punishment policy go hand in hand. Therefore, the findings of the public opinion polls indicating that the proponents of life imprisonment had the support of the public are interesting. The Večer (daily newspaper) asked its readers whether they supported the introduction of life imprisonment or whether Slovenia needed life imprisonment. At the outset of the public debate and at its conclusion (adoption of the law in Parliament), 75 per cent of the respondents supported life imprisonment. ${ }^{33}$ The Slovenian Public Opinion Survey, conducted a year after the introduction of life imprisonment (2009), portrayed the same picture; at the time, 75.5 per cent of Slovenians agreed to the introduction of life imprisonment. ${ }^{34}$

\section{ATTEMPTED ABOLITION OF LIFE IMPRISONMENT IN 2016}

Although the criticism of the introduction of life imprisonment into Slovenian criminal law prevailed in public debate, the penalty became part of the new Criminal Code, which entered into force on 1 November 2008. Since its adoption, the Code was amended several times, and on 4 November 2016, the Ministry of Justice proposed, among other changes, the abolition of life imprisonment. The Ministry grounded the abolition with the following arguments:

- In 2008, life imprisonment was introduced without convincing arguments. The obligation to introduce this penalty does not arise from the Rome Statute, nor is required due to Slovenia's EU membership.

- Tougher punishment does not affect crime trends. At the time of the introduction of life imprisonment, no analyses were made of the crime trends to justify the introduction of life imprisonment, as well as no analysis of how the introduction of life imprisonment in other countries affected the extent of crime.

- The sentence of life imprisonment reflects only retaliation to the perpetrator; however, retaliation or retribution are by no means the primary purposes of punishment.

- In the years following the introduction of this sentence, the system of enforcement of criminal sanctions did not adjust, either on a normative or actual level, to the possibility of enforcing life imprisonment, which is different from the enforcement of other sentences of imprisonment, both in spatial terms and in terms of the treatment of such a convict.

33 M. Mitar and S. Kurdija /2009/: Attitudes towards life sentence in Slovenia 2009 - in: Criminology and crime policy between human rights and effective crime control: book of abstracts (G. Meško and B. Tominc, eds.), Cambridge: The European Society of Criminology; Ljubljana: The Slovenian Academy of Sciences and Arts: The Faculty of Law: The Faculty of Criminal Justice and Security: The Institute of Criminology at the Faculty of Law, p. 45.

34 N. Toš (ed.) /2009/: Vrednote v prehodu IV. Slovensko javno mnenje 2004-2009, Dokumenti SJM, Ljubljana. 
The amendment to the Criminal Code was submitted for professional coordination, and several institutions responded and provided their opinion to the Ministry. The abolition of life imprisonment was explicitly supported by the Slovenian Ombudsman, the Institute of Criminology at the Faculty of Law, and some representatives of the profession. Some institutions stated that they did not oppose the abolition of the life imprisonment (Supreme State Prosecutor's Office, Association of State Prosecutors). The Supreme Court did not form a consensus on the proposed abolition of life imprisonment, and the views of the Supreme Court judges varied. The Institute of Criminology organised a roundtable discussion on life imprisonment, where representatives of some institutions reiterated their views already forwarded to the Ministry. ${ }^{35}$ The public debate on the proposed abolition of life imprisonment was much more modest than at the time it had been introduced. The opponents apparently felt that all arguments opposing the life imprisonment had already been made public in 2007 and 2008 at the time of its introduction and that it was clear from that time the introduction of the life imprisonment was a mistake. Such mistake was also acknowledged by the Ministry proposing abolition of life imprisonment.

But they were wrong. After professional coordination on the proposed amendments to the Criminal Code, the Ministry withdrew the proposal of abolishing the life imprisonment. The Ministry did not reveal any reasons for such decision. Obviously, it was a political decision or a conclusion that such a change did not enjoy unanimous public support and that the proposal would not receive sufficient support in Parliament.

\section{EPILOGUE}

The sentence of life imprisonment was introduced into the Slovenian criminal law for the most serious crimes (in some cases it can be imposed only for the merged crimes), and the possibility of parole is also regulated by law. The latter only means that Slovenia will not be accused of human rights violations by the European Court of Human Rights (at least in light of the Court's current case law). ${ }^{36}$ This does not mean, however, that the state cannot establish higher criteria for respect for human rights. This is what we, the opponents of life imprisonment, were advocating for, though in vain.

The sentence of life imprisonment in Slovenia has not yet been imposed, although it has been on the law for eleven years. What exactly does this imply? That the opponents of its introduction can also be reconciled because the narrow set of crimes and the strict conditions for its imposition make it unlikely that it will ever be imposed? And thus we should accept it since its introduction is not and will not

35 Recording of the roundtable discussion is available at https://www.youtube.com/ watch?v=NkEECPozD_k, 12 October 2019.

36 In several judgments, the ECtHR has recognised the sentence of life imprisonment without parole constitutes a violation of Article 3 of the European Convention on Human Rights. See, for example judgments in Kafkaris v. Cyprus (2008) and Vinter and others v. United Kingdom (2013). 
continue to cause any "harm" in the future? However, this is not the case. Psychology insights demonstrate that the most severe punishment to some extent affects the overall punitive policy.Even if the court does not impose maximum sentences or very rarely does so, it also affects the imposition of higher sentences for offences for which this maximum penalty is not otherwise prescribed. Namely, the maximum penalty in criminal law has the anchoring effect. When assessing a penalty for a particular crime, the judge compares the sentence framework for that crime with the highest sentence in the system. Thus, the most severe punishment becomes the anchor or criterion for assessing the appropriateness of all les severe penalties. ${ }^{37}$ Let us consider how the penal policy of the Slovenian courts has changed since the 1990s when the maximum prison sentence for the most serious crimes also increased.

Until the 1990s, the Slovenian penal system was characterised by the rehabilitative purpose of punishment, ${ }^{38}$ and in recent decades in Slovenia, too, we have noticed trends characteristic of most European countries: at the conceptual level, this is primarily a turn to more retributive rhetoric reflected in the tightening of punishment. The number of prisoners has more than doubled since Slovenia's independence in 1991 (judges impose more prison sentences and longer sentences among them), as a result of different, interrelated reasons, from changes in legislation, changes in relation of public, social and economic changes. ${ }^{39}$ However, this trend is not related to the level of perceived crime. ${ }^{40}$ At least some of the tightening of the penal policy can be explained by the effect of raising the most severe penalty described above.In 1999, a judge compared the three-year prison sentence with 20 years in prison, and later with 30 years in prison, and after 2008 he or she compares it to life imprisonment, so the three-year sentence seems relatively lighter. ${ }^{41}$ To confirm this thesis that raising the maximum sentence has the effect of tightening the penal policy for all crimes, a more extensive and detailed analysis, which has not yet been carried out in Slovenia, would be required. However, the lessons learned from psychology are convincing, and these lessons should be taken into account when introducing a life imprisonment into Slovenian criminal law.

37 M. Mihelj Plesničar /2015/: Tudi sodniki so ljudje: odločanje o sankcijah, kognitivne bližnjice in iskanje poti mimo njih - in: Možgani na zatožni klopi: nevroznanost, kazensko pravo in kriminologija (R. Salecl ed.), IUS Software, GV založba, Inštitut za kriminologijo pri Pravni fakulteti, Ljubljana, pp. 107-129; A. Šelih /2017/: Dosmrtni zapor in njegova odprava, Zbornik znanstvenih razprav, $\mathrm{n}^{\circ}$ 1, pp. 7-23; K. Filipčič /2014/: Kaznovalna politika v Sloveniji - in: Skoraj stoletje profesorja Ljuba Bavcona: parvus liber amicorum. (D. Petrovec, M. Ambrož, eds.), Inštitut za kriminologijo pri Pravni fakulteti, Ljubljana, pp. 34-47.

38 D. Petrovec /1998/: Kazen brez zločina: prispevek k ideologijam kaznovanja, Studia Humanitatis, Ljubljana.

39 M. Mihelj Plesničar and M. Drobnja /2019/: Kaznovanje in kaznovalna politika v Sloveniji: konceptualni premiki in praktične posledice, Revija za kriminalistiko in kriminologijo, $\mathrm{n}^{\circ} 2$, pp. 119-128.

40 However, in the face of the tightening of the sentences imposed, there are two points to be made: (1) Slovenia, with just over 60 prisoners per 100,000 inhabitants, is one of the least oppressive European countries. (2) In the last two decades, some changes to the criminal law have also focused on rehabilitation; elements of restorative justice with the settlement institute and a focus on community work sanctions with the possibility of alternative means of serving shorter prison sentences. 


\section{BIBLIOGRAPHY}

Ambrož M. /2007/: Nova zgradba kaznivega dejanja v predlogu KZ-1, Pravna praksa, $\mathrm{n}^{\circ}$ $41 / 42$.

Ambrož M. /2008/: Spremembe slovenske materialne kazenske zakonodaje in argument primerjalnega prava, Podjetje in delo, $\mathrm{n}^{\circ} 6 / 7$.

Ambrož M. /2008a/: Izvršitev zaporne kazni, ki jo izreče MKS, Pravna praksa, nº 13.

Ambrož M. /2008b/: Poveljniška odgovornost in predlog KZ-1, Pravna praksa, nº 15.

Bavcon L. /2007/: Ali bi Slovenija zmogla brez kazni dosmrtnega zapora?, Pravna praksa, ${ }^{\circ}$ $39 / 40$.

Debenjak B. /2008/: Regeneracija besed pravica, pravičnost, krivda, umno ravnanje: o reformi kazenskega zakonika, Delo, 16. 2. 2008, nº 38.

Deisinger M. /2008/: Nekatere kazenske sankcije v osnutku KZ-1. Pravna praksa, nº 2.

Deisinger M. /2008a/: Kdo se še spomni na holokavst?, Pravna praksa, ${ }^{\circ} 4$.

Filipčič K. /2007/: Časovna odmerjenost učinkov kaznovanja v KZ-1. Pravna praksa, n 46.

Filipčič K. /2008/: Premalo pretehtani posegi v temeljne institute kazenskega prava: o predlogu kazenskega zakonika. Delo, 26. 1. 2008, nº 21.

Filipčič K. /2014/: Kaznovalna politika v Sloveniji - in: Skoraj stoletje profesorja Ljuba Bavcona: parvus liber amicorum. (D. Petrovec, M. Ambrož, eds.), Inštitut za kriminologijo pri Pravni fakulteti, Ljubljana.

Flander B. /2014/: Kaznovanje v Sloveniji (quo vadis) - in: Zbornik prispevkov (B. Flander, I. Areh, M. Modic, eds.), Fakulteta za varnostne vede, Ljubljana, http://www.fvv.uni-mb. si/dv2014/zbornik/Flander.pdf.

Flander B. and Meško G. /2013/: Punitivnost in kaznovalni populizem v Sloveniji, Revija za kriminalistiko in kriminologijo, $\mathrm{n}^{\circ} 4$.

Flander B. and Zupan M. /2007/: Domišljija rablja in ječarja, Pravna praksa, n 41/42.

Ignjatović Đ. /2017/: Kazneni populizam - in: Kaznena reakcija v Srbiji, VII deo, (Đ. Ignjatović, ed.), Univerzitet u Beogradu - Pravni fakultet, Edicija Crimen.

Kmet S. /2007/: Dosmrtni zapor - družba prezira?, Pravna praksa, n 41/42.

Korošec D. /2007/: Temeljno o splošnem pojmu kaznivega dejanja, Pravna praksa, nº 46.

Mihelj Plesničar M. /2015/: Tudi sodniki so ljudje: odločanje o sankcijah, kognitivne bližnjice in iskanje poti mimo njih - in: Možgani na zatožni klopi: nevroznanost, kazensko pravo in kriminologija (R. Salecl ed.), IUS Software, GV založba, Inštitut za kriminologijo pri Pravni fakulteti, Ljubljana.

Mihelj Plesničar M. and Drobnjak M. /2019/: Kaznovanje in kaznovalna politika v Sloveniji: konceptualni premiki in praktične posledice, Revija za kriminalistiko in kriminologijo, $\mathrm{n}^{\circ} 2$.

Mitar M. and Kurdija S. /2009/: Attitudes towards life sentence in Slovenia 2009 - in:. Criminology and crime policy between human rights and effective crime control: book of abstracts (G. Meško and B. Tominc, eds.), Cambridge: The European Society of Criminology; Ljubljana: The Slovenian Academy of Sciences and Arts: The Faculty of Law: The Faculty of Criminal Justice and Security: The Institute of Criminology at the Faculty of Law.

Novak A. /2007/: Dosmrtni zapor na trhlih temeljih, Pravna praksa, n 41/42.

Novak A. /2008/: Nepotrebnost usklajevanja kazenskih sankcij z Rimskim statutom, Pravna praksa, $\mathrm{n}^{\circ} 3$.

Petrovec D. /1998/: Kazen brez zločina: prispevek k ideologijam kaznovanja, Studia Humanitatis, Ljubljana. 
Petrovec D. /2007/: Meje lojalnosti, Pravna praksa, n 41/42.

Šelih A. /2007/: Kazensko pravo kot zakonsko parvo, Pravna praksa, $\mathrm{n}^{\circ} 46$.

Šelih A. /2007a/: Ali potrebujemo nov kazenski zakonik?, Delo, 4.12.2007.

Šelih A. /2017/: Dosmrtni zapor in njegova odprava, Zbornik znanstvenih razprav, $\mathrm{n}^{\circ} 1$.

Toš N. (ed.) /2009/: Vrednote v prehodu IV. Slovensko javno mnenje 2004-2009, Dokumenti SJM, Ljubljana.

Van Zyl Smit D. and Appleton C. /2019/: Life Imprisonment: a global human rights analysis, Harvard University Press, Cambridge, Massachusettes

\author{
Katja Filipčič \\ Pravni fakultet, Univerzitet u Ljubljani, Slovenija
}

\title{
DOŽIVOTNI ZATVOR U SLOVENIJI
}

\begin{abstract}
APSTRAKT
Autorka analizira kaznu doživotnog zatvora koja se u slovenačkom pravu može izreći za dve vrste krivičnih dela - ona koja su predviđena i Rimskim statutom i za teške oblike pojedinih krivičnih dela, uz specifičnost da se mora raditi o njihovom sticaju. U radu se izlaže proces uvođenja ove kazne u Krivični zakonik Slovenije 2008. godine i daje kritički osvrt na izostanak temeljne javne rasprave i neubedljive razloge o harmonizaciji sa Rimskim statutom i evropskim pravom s obzirom na to da se takvo usklađivanje zasniva pre svega na volji država članica, a ne na pravnoj obavezi. Ističe se značaj ljudskih prava u svetlu humanosti i dostojanstva žrtve i učinioca kroz vrednosne aspekte kazne i uslovnog otpusta čija mogućnost je dobro rešenje imajući u vidu praksu Evropskog suda za ljudska prava. Podvlači se uticaj kaznenog populizma koji prati strože kazne i neretko koristi kao političko sredstvo, ali i neuspeli pokušaj ukidanja ove kazne inicijativom ministra pravde iz 2016. godine. Autorka ukazuje na odsustvo istraživanja kriminalne aktivnosti koje bi opravdalo doživotni zatvor i neprilagođenost odredaba o izvršenju krivičnih sankcija ovoj kazni. Pri tom, sâmo postojanje doživotnog zatvora u sistemu kazni ima i psihološki uticaj na sudije prilikom odmeravaja kazne za druga krivična dela čineći tako kriminalnu politiku represivnijom iako za 11 godina ova kazna nijednom nije izrečena.
\end{abstract}

Ključne reči: doživotni zatvor, Rimski statut, kaznena politika, kazneni populizam, ljudska prava. 